\title{
„Es war mir eine Ehre...”
}

\section{Wechsel des Hauptschriftleiters}

\section{Mark Vetter $^{1}$}

Accepted: 4 November 2020 / Published online: 22 November 2020 (c) The Author(s) 2020

Liebe Leserin, lieber Leser,

mit dem Ende des Jahres endet meine Zeit als Hauptschriftleiter der KN, die ich im Jahr 2015 begonnen habe. Nachdem ich im Juni 2020 zum zweiten Mal Vater geworden bin, fällt es mir zunehmend schwer, neben meinen familiären und beruflichen Aufgaben die ehrenamtliche Leitung der Redaktion der Kartographischen Nachrichten zufriedenstellend zu gewährleisten. Als Chefredakteur des wichtigsten Publikationsorgans der DGfK und gleichermaßen der bedeutendsten Fachzeitschrift für die wissenschaftliche Kartographie in Mitteleuropa ist die Verantwortung hoch und die Aufgaben vielfältig.

Ich bin der Meinung, wir haben in den letzten 6 Jahren viel geschafft. Wir haben die nicht leichte Entscheidung des Verlagswechsels im Vorstand und im Vorstandsrat der DGfK getroffen und umgesetzt. Ich denke nach wie vor, dass dies die richtige Entscheidung war. Wir blicken somit mit dem Springer Verlag in eine Zukunft, die die Erfordernisse an ein modernes Fachjournal mit wissenschaftlichem Anspruch ermöglicht, zugleich aber auch dem ebenso wichtigen Vereinsteil in unserer Zeitschrift Raum gibt.

Der wikipedia-Artikel (https://de.wikipedia.org/wiki/ Kartographische_Nachrichten) zu den KN gibt eine Auflistung zu den bisherigen Hauptschriftleitern an: Hans Peter Kosack war 1951 als Schriftleiter tätig und von 1951 bis 1956 hatte Wolfgang Pillewizer das Amt inne. Danach kam Oskar Stollt, der dann 1968 von Hans Ferschke abgelöst wurde. Ihm folgte ab 1988 Jürgen Dodt bis ins Jahr 2000. In den Jahren 2001 und 2002 übernahm Uwe Fichtner die redaktionelle Verantwortung und mein Vorgänger, Rolf Harbeck, war bis zum Jahr 2014 der Hauptschriftleiter der KN.

Glücklicherweise wird auch ab 2021 die Hauptschriftleitung in guten Händen liegen: PD Dr. Dennis Edler von

Mark Vetter

mark.vetter@fhws.de

1 Würzburg, Germany der Ruhr-Universität Bochum wird die Leitung dieser traditionsreichen Zeitschrift übernehmen. Ihm ist immer ein glückliches Händchen für die $\mathrm{KN}$ zu wünschen, ich bin mir ganz sicher, mit ihm eine ideale Besetzung für die Leitung unser Zeitschrift gefunden zu haben. Dennis Edler wird die Mitgliederinteressen der Deutschen Gesellschaft für Kartographie und die Erfordernisse der wissenschaftlichen Kartographie gleichermaßen berücksichtigen.

Ich bedanke mich bei allen Leserinnen und Lesern für Ihre Treue. Mein Dank gilt auch allen Redaktionsmitgliedern, den Akteurinnen und Akteuren in den Verlagshäusern Kirschbaum und Springer für die erfolgreiche Zusammenarbeit.

Herzlichst,

\section{Moruster}

Mark Vetter

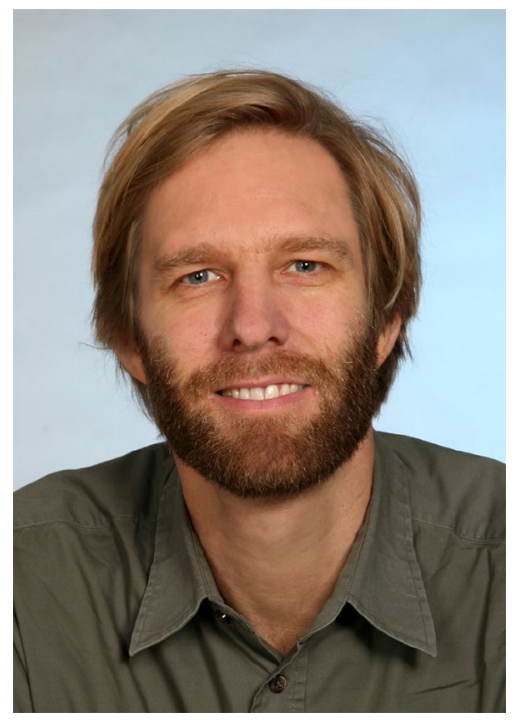


Acknowledgments Open Access funding enabled and organized by Projekt DEAL.

Open Access This article is licensed under a Creative Commons Attribution 4.0 International License, which permits use, sharing, adaptation, distribution and reproduction in any medium or format, as long as you give appropriate credit to the original author(s) and the source, provide a link to the Creative Commons licence, and indicate if changes were made. The images or other third party material in this article are included in the article's Creative Commons licence, unless indicated otherwise in a credit line to the material. If material is not included in the article's Creative Commons licence and your intended use is not permitted by statutory regulation or exceeds the permitted use, you will need to obtain permission directly from the copyright holder. To view a copy of this licence, visit http://creativecommons.org/licenses/by/4.0/. 